Original Article

\title{
MOLECULAR DOCKING STUDY ON 1H-(3,4d) PYRAZOLO-PYRIMIDINES AS CYCLIN DEPENDANT KINASE (CDK2) INHIBITORS
}

\author{
MANISHA S. PHOUJDAR ${ }^{\mathrm{a}, \mathrm{b}}$, GOURISHANKAR R. ALANDc \\ aJawaharlal Nehru Technological University, Hyderabad, India, bSinhgad College of Pharmacy, Vadgaon (BK.), Pune-38, India, cSMT. \\ Kashibai Navale College of Pharmacy, Kondhwa, Pune 48, India \\ Email: mphoujdar@hotmail.com \\ Received: 20 Sep 2016, Revised and Accepted: 15 Nov 2016
}

\section{ABSTRACT}

Objective: CDK2 inhibitors are implicated in several carcinomas viz. Carcinoma of lung, bladder, sarcomas and retinoblastoma. Pyrazolopyrimidines, being purine bioisosters inhibit more than one type of kinase. In this study, we are studying some novel derivatives of $1 \mathrm{H}$ pyrazolo $[3,4 d]$ pyrimidines not reported earlier. The objective of the present study is an attempt towards design and development of $1 \mathrm{H}-[3,4-]$ pyrazolo-pyrimidines as CDK2 inhibitors through rational drug design.

Methods: The present study has been done on CDK2 structure, PDB ID, 3WBL, co-crystallized with ligand PDY from RCSB protein data bank. A series of seventeen $1 H$-Pyrazolo [3,4- $d$ ] pyrimidines feasible for synthesis was docked on the said CDK2 receptor using Auto Dock 4 version, 1.5.6. Outputs were exported to discovery studio 3.5 client for visual inspection of the binding modes and interactions of the compounds with amino acid residues in the active sites.

Results: The results of docking studies revealed that the present series of $1 H$-Pyrazolo[3,4- $d$ ] pyrimidines is showing significant binding through hydrogen bonding, hydrophobic, pi and Van der waals interactions, similar to the ligand PDY. Some conserved H-bond interactions comparable to bioisosters and compounds presently under human trials were noted. Ki values predicted in silico also suggest that the series will show promising CDK2 inhibitory activity.

Conclusion: The series designed and docked can be further developed by synthesis and in vitro and in vivo activity. The receptor inhibitory activity can also be checked by specific receptor assays.

Keywords: Cyclin-dependent kinase-2 inhibitors (CDK2 inhibitors), 3WBL, Pyrazolopyrimidines, AutoDock 4

(C) 2016 The Authors. Published by Innovare Academic Sciences Pvt Ltd. This is an open access article under the CC BY license (http://creativecommons.org/licenses/by/4.0/) DOI: http://dx.doi.org/10.22159/ijcpr.2017v9i1.16625

\section{INTRODUCTION}

Protein kinases are enzymes that modify other proteins by chemically adding $\gamma$ phosphate groups and are known to alter the function of target proteins. Protein kinases remove a phosphate group from ATP and covalently attach it to an amino acid that has a free hydroxyl group $[1,2]$. This usually results in a functional change of the target protein (substrate), by changing enzyme activity, cellular location or association with other proteins. Since the discovery of the first kinase in early 50's, 518 kinases have been discovered till date [3]. This corresponds to around $2 \%$ of the human genome and tells the extraordinary importance of this family in regulating the biological events. Up to $30 \%$ of proteins can be modified by kinase activity, which are known to regulate most of the cellular pathways, especially those involved in signal transduction, cycle progression, growth, differentiation and apoptosis. Protein kinases are turned `ON or OFF' by Phosphorylation, by binding of activator proteins or inhibitory proteins, respectively, or small molecules, or by controlling their location in the cell relative to their substrates. Among them cyclindependent kinases (CDKs), Aurora, Plk-1, Bub1, BubR1, Mps1, Nek kinases and checkpoint kinases, Chk1 and Chk2 are being looked upon as potential anticancer targets $[4,5,5 \mathrm{a}]$

PKs are classified on the basis of specificity to the amino acid they phosphorylate and sequences in the catalytic domain as Tyrosine kinases (PTK), Serine-threonine Kinase and Atypical kinases. Kinases have two structurally and functionally distinct lobes N-lobe and $\mathrm{C}$-lobe, that show unique contributions in both catalysis and regulation of the enzyme activity (fig. 1). The $\mathrm{N}$ and $\mathrm{C}$ lobes are connected to each other with a flexible $C$ helix loop forming a fold over the nucleotide and position the $\gamma$-phosphate of ATP for catalysis. It is unique, dynamic regulatory element in the protein kinase molecule. Both PTK and Serine threonine kinase have a common catalytic core, which consists of a glycine-rich N-terminal ATP binding pocket and a central conserved core consisting of aspartic acid residues which play a vital role in catalytic activity [3]
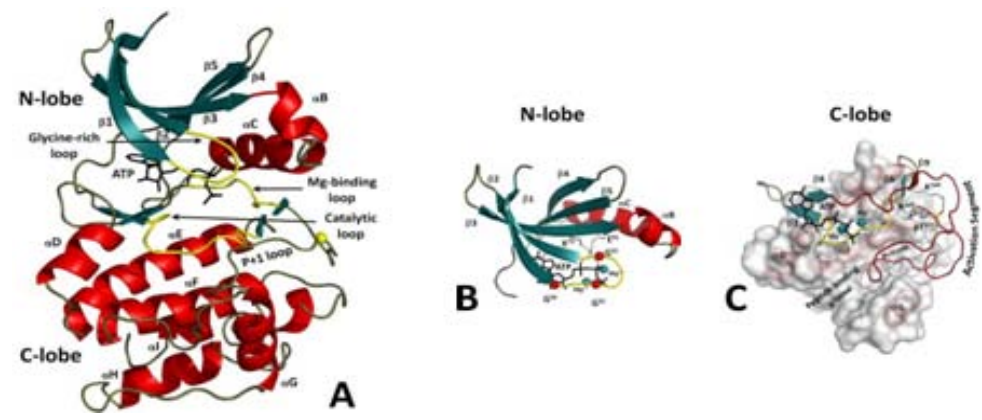

Fig. 1: Structure of the conserved protein kinase core [3] A. Protein kinase with a characteristic bilobal fold. The $\mathrm{N}$-lobe with five $\beta$ strands (steal colored) and $\alpha \mathrm{C}$-helix, mostly helical (colored red). The ATP molecule is bound to a deep cleft between the lobes. Catalytic loops (yellow coloured). B. N-lobe structure with three conserved glycines is shown as red spheres. C. $\mathrm{C}$ lobe, with catalytic and regulatory machinery bound to the rigid helical core 
CDKs are a type of second messenger-dependent serine threonine kinases. They phosphorylate serine or threonine followed by proline. They are active only in the presence of cyclins which form the regulatory subunit. Timely destruction of a particular CDK after their function is over is done through $26 \mathrm{~S}$ proteosome by ubiquination. Numerous Ubiquitin molecules covalently attach to the protein that is to be destructed [6]. When the level of cyclins rises they form a heterodimeric complex with CDKs forming a catalytic complex. These complexes also get activated by phosphorylation of specific sites on CDK thereby forming CAK (CDKactivating Kinases). These activated proteins drive the cell cycle from one phase to another e. g. from G1 to S or G2 to M phase. The CDK subfamily comprises of thirteen members (CDK1 to CDK13) which have a direct impact on transcription, translation and neuronal functions [7].

Overexpression of CDK2 has been seen in colorectal and lung cancer whereas CDK4 is shown to be overexpressed in sarcomas [8]. Overexpressed CDK 4 leads to inactivation of retinoblastoma protein $\mathrm{pRb}$ leading to carcinogenesis. There are about 14 CDK2 inhibitors under clinical trials at various stages (fig. 2 ) with very promising $\mathrm{IC}_{50}$ values [7].

$1 H$-Pyrazolo $[3,4-d]$ pyrimidines derivatives have gained considerable attention due to their reported anticancer and antileukemic activities $[9-13,14]$. The biological effect is attributed to their cyclin-dependent kinase inhibitor [15-17] and tyrosine kinase inhibitory activity [18-19]. The scaffold has also shown potent xanthine oxidase inhibitors and adenosine receptor antagonistic activity[20]. The condensed heterocyclic derivatives have also shown radioprotective activities [10]. Extensive studies have shown pyrazolo[3,4- $d$ ]pyrimidines to have anticancer potential due to multiple target inhibition of epidermal growth factor (EGFR) inhibitors, mammalian target of rapamycin (MTOR) inhibitors[21], Src or dual Src/Abl inhibitors[22], cyclin-dependent kinase (CDK) inhibitors, glycogen synthase kinase-3b (GSK-3b) inhibitors [23-25], xanthine oxidase inhibitors through modulating oxygen stress in cancer cells [26]. Some pyrazolo [1,5a]-1,3,5 triazines, as purine bioisosteres, have also shown potent CDK2 inhibitory activity [27]. The inhibitors have been reported to be placed in the ATP pocket of CDK2 receptor. They interact with hydrophobic interaction and make H-bonds with Kinase, especially with a backbone of Glu 81 and Leu83. These compounds have shown promising activity $\mathrm{IC}_{50}$ of 7 $\mu$ mols [28]. Substituted Indoles [29] and benzopyrans (chromenes) [30] have shown good anticancer activity. Series of 1,3,4 Oxadiazoles substituted with benzimidazole and other aromatic groups have shown promising antitumour activity [31]. Substituted pyrazoles, as well as pyrimidines, have reported promising anticancer potential $[32,33]$. A condensed moiety of the two heterocycles, pyrazolopyrimidine, which is also bioisosteric to purine has been selected for exploring their potential as anticancer agents as specific CDK2 inhibitors. This pyrazolopyrimidine series was taken up for molecular docking study using AutoDock 4 program and further for planned for synthesis and activity assay. This docking study gave us new insights into the CDK2 and helped us to understand the interactions of our compounds with various amino acids in the active site of the receptor.<smiles>CCN1CCN(Cc2ccc(Nc3ncc(F)c(-c4ccc5nc(C)n(C(C)C)c5c4)n3)nc2)CC1</smiles><smiles>CN1CCN(c2ccc(Nc3ncc4cc(C(=O)N(C)C)n(C)c4n3)nc2)CC1</smiles>

LEE011<smiles>CCC(CO)Nc1nc(NCc2ccccc2)c2ncn(C(C)C)c2n1</smiles>

Roscovitine<smiles>CC(C)(C)c1cnc(CSc2cnc(NC(=O)C3CCNCC3)s2)o1</smiles>

SNS-032<smiles>CCc1cnn2c(NCc3cccc([N+](=O)[O-])c3)cc(N3CCC[C@H](CCO)C3)nc12</smiles>

Dinaciclib<smiles>CC(=O)c1c(C)c2cnc(Nc3ccc(N4CCNCC4)cn3)nc2n(C2CCCC2)c1=O</smiles>

Palbociclib

Fig. 2: Some CDK2 inhibitors under clinical trials [7]

\section{MATERIALS AND METHODS}

All computational studies were carried out using AutoDock 4.0 with MGL tools 1.5 .6 on a $2.0 \mathrm{GHz}$ Intel, core i5 processor with 2GB RAM and $2 \mathrm{~TB}$ hard disk with Windows 7 operating system. Ligand 2D structures were drawn using ChemDraw Ultra 7.0 (Chem Office 2010). Chem3D Ultra 7.0 was used to convert 2D structure into 3D. Minimized energy to a minimum RMS gradient of 0.100 was set in each iteration. All structures were saved as pdb file format for input to AutoDockTools (ADT) version 1.5.6. All the ligand structures were then saved in PDBQT files format, for input into AutoDock version 1.5.6.

For the molecular docking study, protein PDB ID was 3WBL of CDK2 was obtained from the RCSB protein data bank. For protein preparation, the co-crystallized ligand PDY, (N7-(4 ethoxyphenyl)-6-methyl-N5-(piperidin-3yl)pyrazolo[3-5 $\alpha]$ pyrimidine-5,7-diamine) on CDK2 was removed, all hydrogen atoms were added, lower occupancy residue structures were deleted, and any incomplete side chains were replaced using the ADT version 1.5.6. Further ADT was used to remove crystal water, Gasteiger charges were added to each atom and non-polar hydrogen atoms were merged with the protein structure. The distance between donor and acceptor atoms that formed hydrogen bond was defined as $1.9 \AA$ with a tolerance of $0.5 \AA$, and the acceptor-hydrogen-donor angle was not less than $120^{\circ}$. The structures were then saved in PDBQT file format, for input into AutoDock version 1.5.6.

The compounds were docked by creating a grid box with a dimension of $40 \times 40 \times 40 \AA$ and centred on $28.946,64.147,8.5596$ around the binding site of ligand PDY on CDK2 receptor using AutoDock tools. The centre of the box was set at PDY and grid energy calculations were carried out. For AutoDock docking calculation, default parameters were used and 10 docked conformations were generated for each compound.

In order to verify the reproducibility of the docking calculations, the bound ligand (PDY) was extracted from the complexes and redocked with above docking protocol. Docking protocol was validated by docking the PDY, which reproduced the PDY bioactive conformer with RMSD less than 1 (fig. 3). The outputs were exported to discovery studio for visual inspection of the binding modes and interactions of the compounds with amino acid residues in the active site. 


\section{RESULTS AND DISCUSSION}

Serine threonine kinase (CDK2), a clinically validated target for the treatment of various lymphomas and sarcomas has received considerable interest from the scientist in design and development of newer anticancer drugs. Molecular docking studies were performed on 17 structurally diverse, proposed, substituted $1 H$-Pyrazolo $[3,4-d]$ pyrimidines on CDK-2 (PDB ID-3WBL) using AutoDock 4 model. Docking results show notable interactions of ligands and receptor that include-H bond interactions with backbone carbonyl group of Asp A: 86 and Leu A: 83, hydrophobic and pi alkyl interactions with amino acids Leu A: 134, Val A: 18 and Ala A: 31, Van der Waals interactions with Gly A: 11, amide and pi staked amide interactions with ILE A: 10. Wherever halogens are present (Fluorine) they are seen to interact with GlyA: 11 . Some unfavourable interactions are also seen with Val 18 (with fluorine) of IIIb, Leu 83 (with pyrimidine ring), Leu 133(with phenyl ring) of IIIe, and Asp A: 145 (with Pyrazolopyrimidines) scaffold of IIc. Asp A: 145 shows both favourable and unfavourable interactions with- $\mathrm{OCH}_{3}$ of Ic and Id. The binding free energy of Ligand PDY with the receptor is-7.93 Kcal, which is comparable to binding free energy between-6.85 Kcal/mol (Ij) to-8.64 Kcal/mol(IIla of the proposed series. Compounds Ig, IIb, IIIa, IIIb and IIId, show lower binding free energy as well as better Ki than ligand PDY and can be looked upon for further development.

Similar docking studies are carried out on CDK2 receptors on benzopyrazole derivatives [34] show binding interactions with Lys 33 and Leu 83, docking studies on $1 H$ pyrazole derivatives [35] have shown H-bond interactions with Ile 10, Lys 89 and Asp145. Studies carried out on oxindoles, indole and purine derivatives show $\mathrm{H}$-bond interactions with the carbonyl group of Gln 131, Leu 83, Lys 89 and Asp86 with very good predicted and actual $\mathrm{IC}_{50}$ [36]. A potent CDK2 inhibitor developed with cycloalkyl amino thiazolyl scaffold (BMS387032) has shown $2 \mathrm{H}$ bonds with Leu83 in the active site. This compound has proven to be an effective and selective inhibitor and has entered phase I human clinical trials [37]. The conserved interactions that our compounds show suggest that these proposed set of compounds can be developed as potent CDK2 inhibitors.

Various docked conformations and active Site interactions with CDK-2 receptor have been shown in fig. 3. Further details of important amino acid interactions with CDK2 receptor with Predicted Ki values are shown in table 1 and key interactions of compounds at the binding site with bond lengths in Á are shown intable 2.
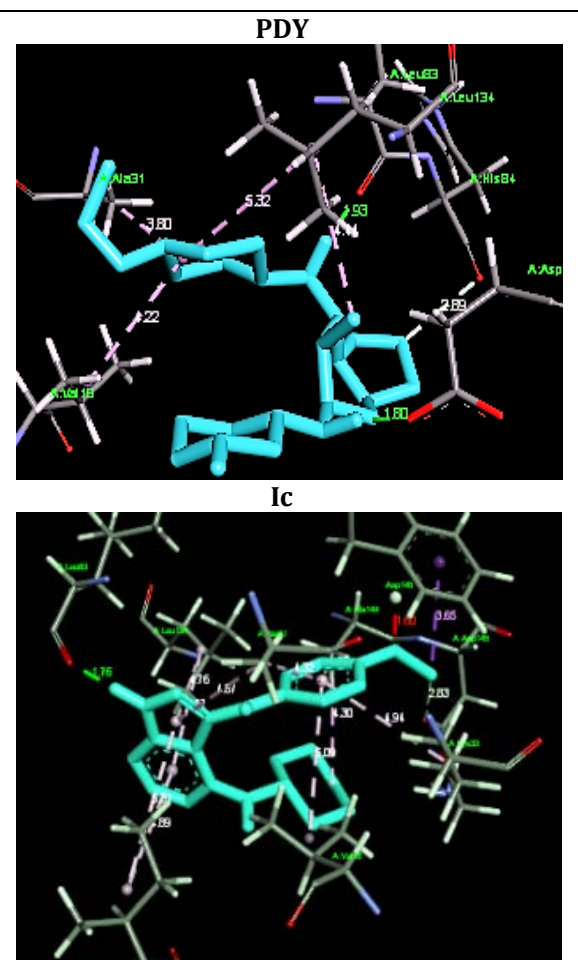

If

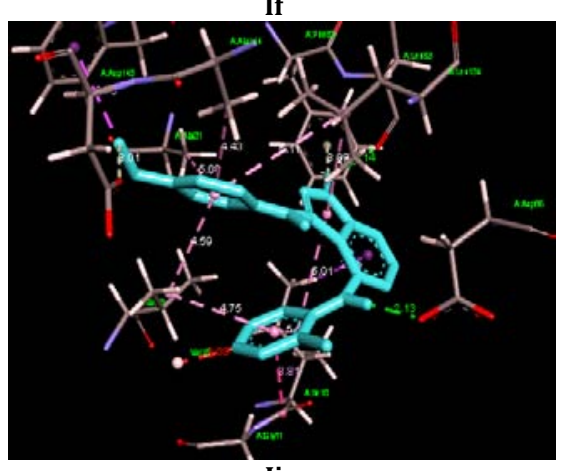

Ij

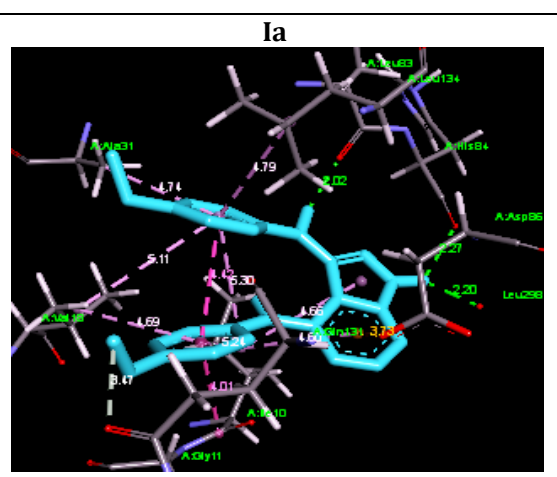

Id

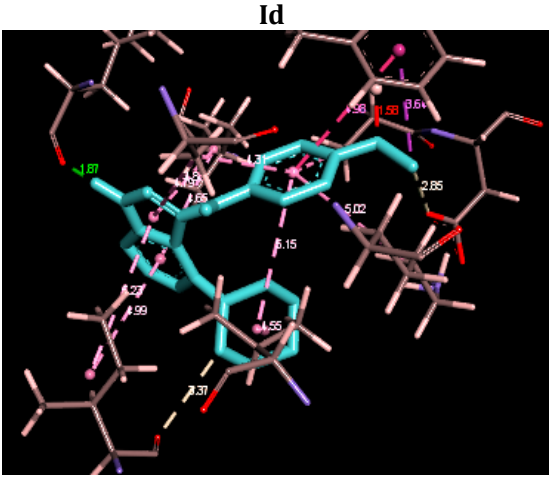

Ig

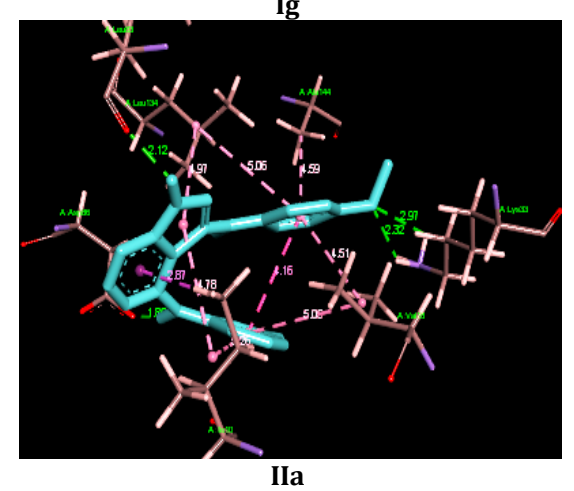

Ib

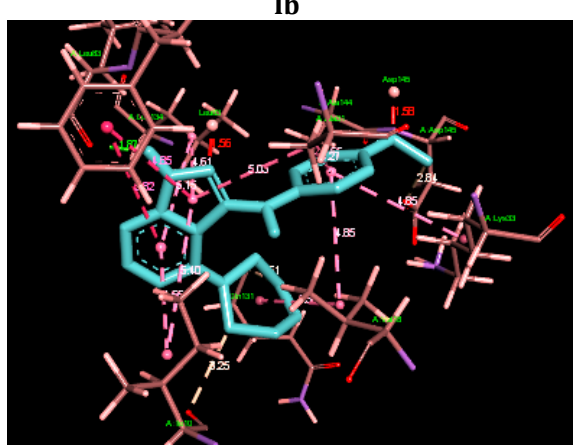

Ie

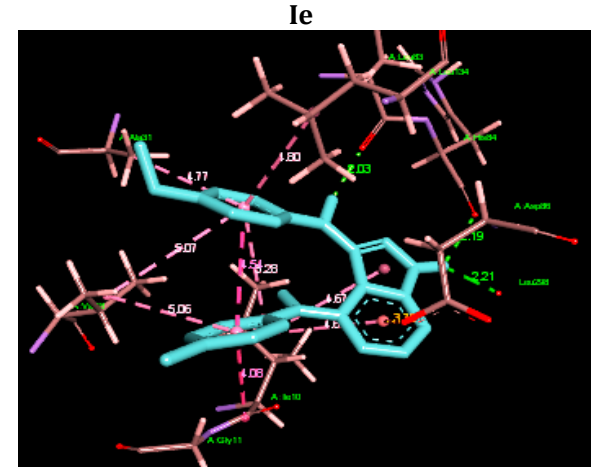

Ih

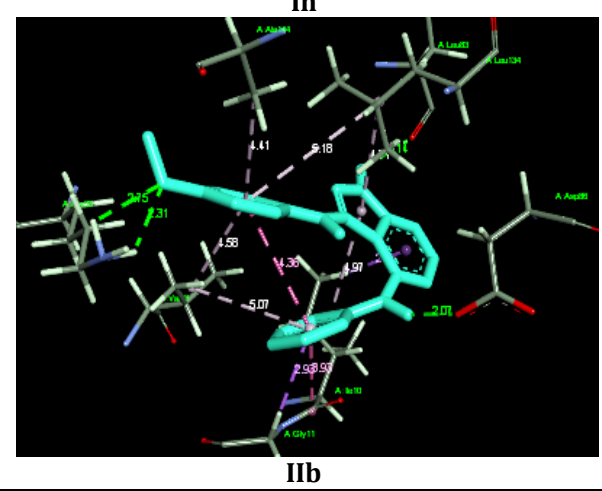



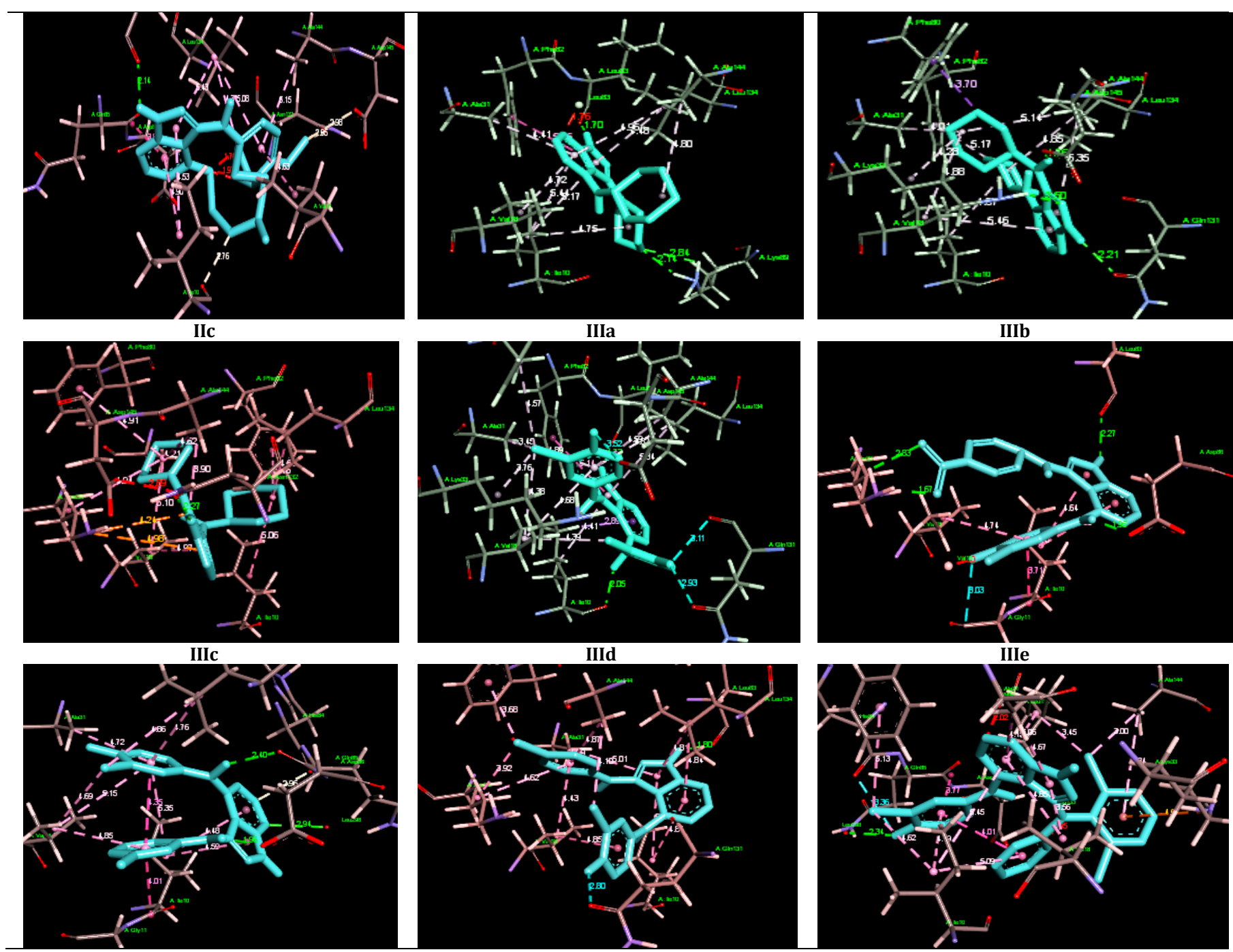

Fig. 3: Docked conformations and active site interactions with CDK-2 receptor

Table 1: Important amino acid interactions with CDK2 receptor with predicted Ki values

\begin{tabular}{|c|c|c|c|c|c|}
\hline $\begin{array}{l}\text { S. } \\
\text { No. }\end{array}$ & Name & Structure & $\begin{array}{l}\text { Ki } \\
(\mu \mathrm{mol})\end{array}$ & $\begin{array}{l}\text { Binding free } \\
\text { energy Kcal/mol }\end{array}$ & Important interactions-interacting residues \\
\hline 1. & PDY & & 1.54 & -7.93 & $\begin{array}{l}\text { H-bonds-ASP A: 86, LEU A: } 83 \\
\text { Alkyl-LEU A: 34, ALA A: 31, VAL A: } 18 \\
\text { C-H-HIS A: } 84\end{array}$ \\
\hline 2. & Ia & & 3.42 & -7.46 & $\begin{array}{l}\text { H-bonds-HIS A: 83, LEU A: 298, LEU A: 83; pi-Alkyl- } \\
\text { LEU A: 134, ALA A: 31, VAL A: 18;. pi-anion-ASP A: 86; } \\
\text { C-H-GLN A: 131; Van der waals-GLY A: } 11\end{array}$ \\
\hline 3. & $\mathrm{Ib}$ & & 6.53 & -7.07 & $\begin{array}{l}\text { H-bonds-LYS A: 33, GLN A: 131, ASN A: 132, ASP A: } \\
\text { 145; Alkyl and pi Alkyl-ALA A: 144, VAL A: 18, ALA A: } \\
\text { 31, PHE A: 82, LEU A: 134. C-H-ASP A: } 86\end{array}$ \\
\hline 4. & Ic & & 1.4 & -7.99 & $\begin{array}{l}\text { H-bonds-LEU A: 83; Alkyl and pi Alkyl-ILE A: 10, LEU } \\
\text { A: 134, VAL A: 18, ALA A: 31, LYS A: 33, ALA A: 144; C- } \\
\text { H-ASP A: 145; pi-Sigma-PHE A: 80; Unfavourable } \\
\text { bumps-ASP A: } 145\end{array}$ \\
\hline 5. & Id & & 3.14 & -7.51 & $\begin{array}{l}\text { H-bonds-LEU A: 83; Alkyl and pi Alkyl-LEU A: 134, } \\
\text { ALA A: 31, LYS A: 33,ALA A: 144,VAL A: 18. C-H-ASP A: } \\
\text { 145. C-H-ASP A: 145; pi-Sigma-PHE A: } 80 \\
\text { Unfavourable bumps-ASP A: } 145\end{array}$ \\
\hline
\end{tabular}




H. Ie
ASP A: 86. C-H-ASP A: 145. Alkyl-VAL A: 18, ALA A: 31,
LEU A: 134; Van der waals-GLY A: 11

\begin{tabular}{|c|c|c|c|c|c|}
\hline $\begin{array}{l}\text { S. } \\
\text { No. }\end{array}$ & Name & Structure & $\begin{array}{l}\text { Ki } \\
(\mu \mathrm{mol})\end{array}$ & $\begin{array}{l}\text { Binding free } \\
\text { energy } \\
\text { Kcal/mol }\end{array}$ & Important interactions-interacting residues \\
\hline 8. & Ig & & 2.3 & -7.69 & $\begin{array}{l}\text { H-bonds-ASP A: 86, LYS A: 33, LEU A: 83; Pi alkyl-VAL A: 18, } \\
\text { LEU A: 134, ALA A: 144; pi-Sigma-PHEA: } 80 \text { and ILE A: 10; } \\
\text { Unfavourable bumps-ILE A: } 10\end{array}$ \\
\hline 9. & Ih & & 3.13 & -7.51 & $\begin{array}{l}\text { H-bonds-LYS A: 33, LEU A: 83, ASP A: 86; pi-alkyl-VAL A: 18, } \\
\text { ALA A: 144, LEU A: 134; pi-Sigma-ILE A: 10, GLY A11 }\end{array}$ \\
\hline 10. & $\mathrm{Ij}$ & & 9.55 & -6.85 & $\begin{array}{l}\text { H-bonds-ASP A: } 86 \text { and LEU A: 83; Amide pi stacked-ILE A: } \\
\text { 10; pi-alkyl-VAL A: 18, LEU A: 134,ALA A: 144. C-H-ALA A: 31; } \\
\text { Van der waals-GLY A: } 11\end{array}$ \\
\hline 11. & IIa & & 6.9 & -7.04 & $\begin{array}{l}\text { H-bonds-LEU A: } 83 \text { and LYS A: } 89 \\
\text { Alkyl and pi-alkyl-ILE A: 10, VAL A: 18, ALA A: } 31 \text { and ALA A: } \\
\text { 144. pi-pi stacked-PHE A: } 82 \text {; Unfavourable bumps-LEU A: } 83\end{array}$ \\
\hline 12. & IIb & & 1.71 & -7.87 & $\begin{array}{l}\text { H-bonds-LYS A: 33, GLN A: 131, and ASP A: 145. Alkyl and pi- } \\
\text { alkyl-ILE A: 10, VAL A: 18, PHE A: 82, ALA A: 31, ALA A: 144; } \\
\text { pi-Sigma-PHE A: } 80\end{array}$ \\
\hline 13. & IIc & & 3.36 & -7.47 & $\begin{array}{l}\text { H-bond-ASN A: 132; Alkyl and pi-alkyl-ILE A: 10, ALA A: 31, } \\
\text { PHE A: 80, PHE A: 82, VAL A: } 18 \text { and LEU A: 134; pi-Cationic- } \\
\text { LYS A: 33; Unfavourable bumps-ASP A: } 145\end{array}$ \\
\hline 14. & IIIa & & 2.89 & -7.56 & $\begin{array}{l}\text { H-bond-ILE A: 10, LEU A: 83; Alkyl and pi-alkyl-VAL A: 18, } \\
\text { ALA A: 31, LYS A: 33, PHE A: 80, LEU A: 134, ALA A: 144; pi-pi } \\
\text { Stacked-PHE A: 82; Halogen-GLN A: 131, ASP A: } 145\end{array}$ \\
\hline 15. & IIIb & & 0.460 & -8.64 & $\begin{array}{l}\text { H-bond-LYS A: 33, LEU A: } 83 \text { and ASP A: } 86 . \text { Amide pi stacked- } \\
\text { ILE A: 10; } \\
\text { pi-alkyl and alkyl-VAL A: 18; Halogen-GLY A: 11; } \\
\text { unfavourable bumps-VAL: } 18\end{array}$ \\
\hline
\end{tabular}

\begin{tabular}{|c|c|c|c|c|c|}
\hline $\begin{array}{l}\text { S. } \\
\text { No. }\end{array}$ & Name & Structure & $\begin{array}{l}\text { Ki } \\
(\mu \mathrm{mol})\end{array}$ & $\begin{array}{l}\text { Binding free energy } \\
\text { Kcal/mol }\end{array}$ & Important interactions-interacting residues \\
\hline 16. & IIIc & & 2.36 & -7.68 & $\begin{array}{l}\text { H-bond-GLN A: } 85 \text {, ASP A: 86, LEU 298; Amide pi stacked- } \\
\text { ILE A: 10; pi-alkyl and alkyl-VAL A: 18, ALA A: } 31 \text { and LEU } \\
\text { A: 134; C-H bond-HIS A: 84; Van der waals-GLY A: } 11\end{array}$ \\
\hline 17. & IIId & & 1.33 & -8.01 & $\begin{array}{l}\text { H-bond-LEU A: 83; pi-alkyl and alkyl-ILE A: 10, VAL A: 18, } \\
\text { ALA A: 31,LYS A: 33, PHE A: 80, LEU A: } 134 \text { and ALA A: } \\
\text { 144; } \\
\text { Halogen-GLN A: } 131\end{array}$ \\
\hline 18. & IIIe & & 10.12 & -6.89 & $\begin{array}{l}\text { H-bond-LEU 298; Amide pi stacked-GLN A: 85; pi-alkyl } \\
\text { and alkyl-VAL A: 18, ALA A: 31, PHE A: 82, ILE A: 10, ALA } \\
\text { A: } 144 \text { and LEU A: 134; Van der waals-ASP A: 86; } \\
\text { Unfavourable bump-LEU A: } 83 \text { and LEU: 133. pi-cation- } \\
\text { LYS A: 33; Halogen-HIS A: } 84\end{array}$ \\
\hline
\end{tabular}


Table 2: Key interactions of compounds at binding site with bond lengths in $\AA$.

\begin{tabular}{|c|c|c|c|c|c|c|c|c|c|c|c|c|c|c|c|c|c|c|c|c|}
\hline $\begin{array}{l}\text { S. } \\
\text { No } \\
\text {. }\end{array}$ & $\begin{array}{l}\text { CDK2 } \\
\text { Inhibitor } \\
\text { s }\end{array}$ & $\begin{array}{l}\text { LEU } \\
\text { A: } \\
83\end{array}$ & $\begin{array}{l}\text { ASP } \\
\text { A: } \\
86\end{array}$ & $\begin{array}{l}\text { LEU } \\
\text { A: } \\
298\end{array}$ & $\begin{array}{l}\text { AS } \\
\text { N } \\
\text { A: } \\
132\end{array}$ & $\begin{array}{l}\text { GL } \\
\text { N } \\
85\end{array}$ & $\begin{array}{l}\text { Lys } \\
\text { A: } \\
89\end{array}$ & $\begin{array}{l}\text { ILE } \\
\text { A: } \\
10\end{array}$ & $\begin{array}{l}\text { LEU } \\
\text { A: } \\
134\end{array}$ & $\begin{array}{l}\text { VA } \\
\text { L A: } \\
134\end{array}$ & $\begin{array}{l}\text { VAL } \\
\text { A: } \\
18\end{array}$ & $\begin{array}{l}\text { Ala } \\
\text { A: } \\
144\end{array}$ & $\begin{array}{l}\text { ALA } \\
\text { A: } \\
\mathbf{3 1}\end{array}$ & $\begin{array}{l}\text { PH } \\
\text { E A: } \\
82\end{array}$ & $\begin{array}{l}\text { PH } \\
\text { E A } \\
80\end{array}$ & $\begin{array}{l}\text { ASP } \\
\text { A: } \\
145\end{array}$ & $\begin{array}{l}\text { GL } \\
\text { Y A: } \\
11\end{array}$ & $\begin{array}{l}\text { GL } \\
\text { N } \\
\text { A: } \\
131\end{array}$ & $\begin{array}{l}\text { Lys } \\
\text { A: } \\
33\end{array}$ & $\begin{array}{l}\text { HIS } \\
\text { A: } \\
84\end{array}$ \\
\hline & PDY & $\begin{array}{l}1.9 \\
3\end{array}$ & $\begin{array}{l}1.8 \\
0\end{array}$ & $\begin{array}{l}2.2 \\
0\end{array}$ & & & & & $\begin{array}{l}5.3 \\
2\end{array}$ & & $\begin{array}{l}4.2 \\
2\end{array}$ & & $\begin{array}{l}3.8 \\
0\end{array}$ & & & & & & & $\begin{array}{l}2.8 \\
9\end{array}$ \\
\hline 1. & Ia & 2.02 & $* * *$ & 2.20 & & & & $\begin{array}{l}4.4 \\
2\end{array}$ & 4.79 & & 4.69 & & 4.74 & & & & & $\begin{array}{l}2.2 \\
0\end{array}$ & & 2.27 \\
\hline 2. & $\mathrm{Ib}$ & & 3.39 & & $\begin{array}{l}2.8 \\
7\end{array}$ & & & & 3.55 & & 4.94 & $\begin{array}{l}4.4 \\
1\end{array}$ & 4.27 & $\begin{array}{l}5.4 \\
0\end{array}$ & & 1.91 & & $\begin{array}{l}2.1 \\
2\end{array}$ & $\begin{array}{l}2.4 \\
8\end{array}$ & \\
\hline 3. & Ic & 1.76 & 2.83 & & & & & $\begin{array}{l}4.8 \\
9\end{array}$ & 4.76 & & 5.09 & & 4.30 & & & $\begin{array}{l}2.83 \\
*\end{array}$ & & & $\begin{array}{l}4.9 \\
4\end{array}$ & \\
\hline 4. & Id & 1.87 & & & & & & $\begin{array}{l}4.9 \\
9\end{array}$ & 4.88 & & 4.55 & & & & & $\begin{array}{l}1.98 \\
*\end{array}$ & & & $\begin{array}{l}5.0 \\
2\end{array}$ & \\
\hline 5. & Ie & 2.03 & 3.73 & 2.21 & & & & $\begin{array}{l}4.0 \\
8\end{array}$ & & & & & & & & & & & & 2.19 \\
\hline 6. & If & 2.14 & 2.13 & & & & & $\begin{array}{l}2.7 \\
5\end{array}$ & 4.71 & & 4.59 & & 5.08 & $\begin{array}{l}3.0 \\
9\end{array}$ & $\begin{array}{l}3.7 \\
5\end{array}$ & 3.01 & & & & \\
\hline 7. & Ig & 2.12 & 1.85 & & & & & $\begin{array}{l}2.8 \\
7\end{array}$ & 4.59 & & 4.51 & $\begin{array}{l}4.5 \\
9\end{array}$ & & & & & & & $\begin{array}{l}2.3 \\
2\end{array}$ & \\
\hline 8. & Ih & 2.14 & 2.07 & & & & & $\begin{array}{l}2.8 \\
5\end{array}$ & 5.18 & & 4.58 & $\begin{array}{l}4.4 \\
1\end{array}$ & & & & & $\begin{array}{l}2.9 \\
3\end{array}$ & & $\begin{array}{l}2.3 \\
1\end{array}$ & \\
\hline 9. & Ij & 2.21 & 1.97 & & & & & $\begin{array}{l}3.7 \\
5\end{array}$ & 5.02 & & 4.25 & & 3.06 & & & & & & & \\
\hline 10. & IIa & 1.70 & & & & & $\begin{array}{l}2.1 \\
4\end{array}$ & $\begin{array}{l}4.7 \\
5\end{array}$ & 4.48 & & 4.72 & 4.8 & 4.41 & $\begin{array}{l}4.9 \\
6\end{array}$ & & & & & & \\
\hline 11. & IIb & & & & & & & $\begin{array}{l}4.8 \\
7\end{array}$ & 4.16 & $\begin{array}{l}4.1 \\
8\end{array}$ & 5.41 & & 4.01 & $\begin{array}{l}5.1 \\
7\end{array}$ & $\begin{array}{l}3.7 \\
0\end{array}$ & 1.76 & & $\begin{array}{l}2.5 \\
0\end{array}$ & $\begin{array}{l}2.2 \\
1\end{array}$ & \\
\hline 12. & IIc & & & & $\begin{array}{l}2.2 \\
7\end{array}$ & & & $\begin{array}{l}6.0 \\
6\end{array}$ & & & & & & & $\begin{array}{l}4.9 \\
1\end{array}$ & 2.89 & & & $\begin{array}{l}4.2 \\
4\end{array}$ & \\
\hline 13. & IIIa & & & & & & & $\begin{array}{l}4.8 \\
7\end{array}$ & 4.26 & 4.3 & & $\begin{array}{l}4.0 \\
1\end{array}$ & & $\begin{array}{l}5.1 \\
7\end{array}$ & & 1.76 & & $\begin{array}{l}2.2 \\
1\end{array}$ & $\begin{array}{l}2.5 \\
0\end{array}$ & \\
\hline 14. & IIIb & 2.27 & 1.96 & & & & & $\begin{array}{l}3.7 \\
1\end{array}$ & & & & & & & & & $\begin{array}{l}3.0 \\
3\end{array}$ & & $\begin{array}{l}1.6 \\
7\end{array}$ & \\
\hline 15. & IIIC & & 1.96 & 2.94 & & 2.4 & & & 4.76 & & 4.69 & & 4.72 & & & & $\begin{array}{l}2.9 \\
6\end{array}$ & & & 2.0 \\
\hline 16. & IIId & 1.8 & & & & & & $\begin{array}{l}4.8 \\
7\end{array}$ & 4.81 & & 4.43 & & 4.10 & & & & & 2.8 & $\begin{array}{l}3.9 \\
2\end{array}$ & \\
\hline 17. & IIIe & 2.03 & & 2.34 & & & & $\begin{array}{l}5.4 \\
5\end{array}$ & 5.06 & & 4.1 & & 3.0 & & & & & & & 3.36 \\
\hline
\end{tabular}

*In compound Ic and Id-ASP 145 interacts with- $\mathrm{OCH}_{3}$ group of with 2 types of Interaction-It shows $\mathrm{C}-\mathrm{H}$ type of interaction with- $\mathrm{CH}_{3}$ of-OCH${ }_{3}$ and unfavourable bump with-O of- $\mathrm{OCH}_{3}$

\begin{tabular}{|c|c|c|c|c|c|c|c|c|c|}
\hline H-bond & $\mathrm{C}-\mathrm{H}$ & Alkyl/pi alkyl & pi carbon & Van der waals & Halogen & Unfavourable & Pi amide & pi-pi stacked & PI SIGMA \\
\hline
\end{tabular}

\section{CONCLUSION}

This work has shown interesting results in terms of interactions with various amino acids in the active site of the CDK2 receptor, binding free energy and predicted Ki values. This series can be further taken up for the development of selective and effective CDK2 inhibitors as anticancer agents.

\section{ACKNOWLEDGEMENT}

The authors acknowledge the research funds received from Savitribai Phule Pune University and Sakal Research Foundation. The authors also acknowledge the facilities provided by Sinhgad Technical Education Society to carry out the research work.

\section{CONFLICT OF INTERESTS}

Declared none

\section{REFERENCES}

1. Cheek S, Zhang H, Grishin NV. Sequence and structure classification of kinases. J Mol Biol 2002;320:855-81.

2. McConnell JL, Wadzinski BE. Targeting protein serine/ threonine phosphatases for drug development. Mol Pharmacol 2009;75:1249-61.

3. Taylor SS, Kornev AP. Protein kinases: evolution of dynamic regulatory proteins. Trends Biochem Sci 2011;36:65-77.

4. Fischer PM. The use of CDK 2 inhibitors in cancer. Cell Cycle 2004;3:742-6.

5. Kim DC, Lee YR, Yang BS, Shin KJ, Kim DJ, Chung BY, et al. Synthesis and biological evaluations of pyrazolo [3,4- d]pyrimidines as cyclin-dependent kinase 2 inhibitors. Eur J Med Chem 2003;38:525-32.

6. 5a. Balajee R, Dhana Rajan MS. Comparative study of inhibition of drug potencies of tyrosine kinase inhibitors: a computational and molecular docking study. Asian J Pharm Clin Res 2012;1:104-8.

7. Shchemelinin I, Šefc L, Nečas E. Protein kinases, their function and implication in cancer and other diseases. Folia Biol (Praha) 2006;52:81-101.

8. Mariaule G, Belmont P. Cyclin-dependent kinase inhibitors as marketed anticancer drugs: where are we now? a short survey. Molecules 2014;19:14366-82.

9. Balakrishnan A, Vyas A, Deshpande K, Vyas D. Pharmacological cyclin-dependent kinase inhibitors: implications for colorectal cancer. World J Gastroenterol 2016;21(22 Suppl 7):2159-64.

10. Ghorab MM, Ragab FA, Alqasoumi SI, Alafeefy AM, Aboulmagd SA. Synthesis of some new pyrazolo [3,4-d]pyrimidine derivatives of expected anticancer and radioprotective activity. Eur J Med Chem 2010;45:171-8.

11. Rashad AE, Mahmoud AE, Ali MM. Synthesis and anticancer effects of some novel pyrazolo [3,4- $d]$ pyrimidine derivatives by generating reactive oxygen species in human breast adenocarcinoma cells. Eur J Med Chem 201;4:1019-26.

12. El-Enany MM, Kamel MM, Khalil OM, El-Nassan HB. Synthesis and antitumor activity of novel 6-aryl and 6-alkylpyrazolo[3,4d]pyrimidin-4-one derivatives. Eur J Med Chem 2010;45:5286-91.

13. Kumar A, Ahmad I, Chhikara BS, Tiwari R, Mandal D, Parang K. Synthesis of 3-phenyl pyrazolopyrimidine-1,2,3-triazole conjugates and evaluation of their Src kinase inhibitory and anticancer activities. Bioorg Med Chem Lett 2011;21:1342-6. 
14. Hassan GS, Kadry HH, Abou-Seri SM, Ali MM, Mahmoud AE. Synthesis and in vitro cytotoxic activity of novel pyrazolo[3,4d]pyrimidines and related pyrazole hydrazones towards breast adenocarcinoma MCF-7 cell line. Bioorg Med Chem 2011;19:6808-17.

15. Pal D, Saha S, Singh A. Importance of pyrazole moeity in the field of cancer. Int J Pharm Pharn Sci 2012;4:98-104.

16. Kim DC, Lee YR, Yang B, Shin KJ, Kim DJ, Chung BY, et al. Synthesis and biological evaluations of pyrazolo[3,4d]pyrimidines as cyclin-dependent kinase 2 inhibitors. Eur J Med Chem 2003;38:525-32.

17. Markwalder JA, Arnone MR, Benfield PA, Boisclair M, Burton $\mathrm{CR}$, Chang $\mathrm{C}$, et al. Synthesis and biological evaluation of 1-Aryl4,5-dihydro-1H-pyrazolo[3,4-d]pyrimidin-4-one inhibitors of cyclin dependent kinases. J Med Chem 2004;47:5894-911.

18. Peat AJ, Boucheron JA, Dickerson SH, Garrido D, Mills W, Peckham J, et al. Novel pyrazolopyrimidine derivatives as GSK3 inhibitors. Bioorg Med Chem Lett 2004;14:2121-5.

19. Schenone S, Bruno O, Bondavalli F, Ranise A, Mosti L, Menozzi G. Antiproliferative activity of new 1-aryl-4-amino-1H-pyrazolo[3,4d]pyrimidine derivatives toward the human epidermoid carcinoma A431 cell line. Eur J Med Chem 2004;39:939-46.

20. Ducray R, Ballard P, Barlaam BC, Hickinson MD, Kettle JG, Ogilvieb DJ, et al. Novel 3-alkoxy-1H-pyrazolo[3,4d]pyrimidines as EGFR and erbB2 receptor tyrosine kinase inhibitors. Bioorg Med Chem Lett 2008;18:959-62.

21. Schenone S, Bruno O, Bondavalli F, Ranise A, Mosti L, Menozzi $\mathrm{G}$, et al. Synthesis of 1-(2-chloro-2-phenylethyl)-6-methylthio$1 \mathrm{H}$-pyrazolo[3,4-d]pyrimidines 4-amino substituted and their biological evaluation. Eur J Med Chem 2004;39:153-60.

22. Curran KJ, Verheijen JC, Kaplan J, Richard DJ, Toral-Barza L, Hollander I. pyrazolopyrimidines as highly potent and selective, ATP-competitive inhibitors of the mammalian target of rapamycin (mTOR): optimisation of the 1-substituent. Bioorg Med Chem Lett 2010;20:1440-4.

23. Schenone S, Brullo C, Bruno O, Bondavalli F, Mosti L, Maga G, et al. Synthesis, biological evaluation and docking studies of 4amino substituted 1H-pyrazolo[3,4-d]pyrimidines. Eur J Med Chem 2008;43:2665-76.

24. Peat AJ, Garrido D, Boucheron JA, Schweiker SL, Dickerson SH, Wilson JR, et al. Novel GSK-3 inhibitors with improved cellular activity. Bioorg Med Chem Lett 2004;14:2127-30.

25. Smalley TL, Peat AJ, Boucheron JA, Dickerson S, Garrido D, Preugschat F. Synthesis and evaluation of novel heterocyclic inhibitors of GSK-3. Bioorg Med Chem Lett 2006;16:2091-4.

26. Luma C, Kahl J, Kessler L, Kucharski J, Lundstrm J, Miller S. 2,5Diaminopyrimidines and 3,5-disubstituted aza purines as inhibitors of glycogen synthase kinase-3 (GSK-3). Bioorg Med Chem Lett 2008;18:3578-81.

27. Rashad AE, Mahmoudb AE, Ali MM. Synthesis and anticancer effects of some novel pyrazolo[3,4- $d]$ pyrimidine derivatives by generating reactive oxygen species in human breast adenocarcinoma cells. Eur J Med Chem 2011;46:1019-26.

28. Popowycz F, Fournet G, Schneider C, Bettayeb K, Ferandin Y, Lamigeon C, et al. Pyrazolo[1,5-a]-1,3,5-triazine as a purine bioisostere: access to potent cyclin-dependent kinase inhibitor (R)-roscovitine analogue. J Med Chem 2009;52:655-63.

29. Abdulilah E, Sevin F. The discovery of potential cyclin A/CDK2 inhibitors: a combination of 3D QSAR pharmacophore modeling, virtual screening, and molecular docking studies. Med Chem Res 2013;22:5832-43

30. Biswal S, Sahoo U, Sethy S, Kumar HKS, Banerjee M. Indole: the molecule of diverse biological activities. Asian J Pharm Clin Res 2012;5:1-6.

31. Thomas N, Zachariah SM. Pharmacological activities of chromene derivatives: an overview. Asian J Pharm Clin Res 2013;6:11-5.

32. Kavitha S, Gnanavel S, Kannan K. Biological aspects of 1,3,4 oxadiazole derivatives. Asian J Pharm Clin Res 2014;7:11-20.

33. Ray S, Charusmriti. A QSAR study at AM1 semi-empirical level of 1,3-diaryl pyrazole derivatives as antitumor agents against human DU145 prostrate cancer cell line. Asian J Pharm Clin Res 2012;5:160-3.

34. Eatedal HA, Nermine AM, Amany MM, Alaa NH. Synthesis of new pyrimidine derivatives and evaluation of their anticancer and antimicrobial activities. Asian J Pharm Clin Res 2016;9:306-13.

35. Guttikonda V, Raavi D, Maadwar SK, Gade RD. Molecular insights of benzopyrazole as CDK2 inhibitors: combined molecular docking, molecular dynamics, and 3D QSAR studies. J Recept Signal Transduct Res 2015;35:439-49.

36. Chandra, Javaregowda VG, Doreswamy BH, Ningaiah $S$, Bhadraiah UK, Kemparaju K, et al. Molecular docking studies of $1 H$ pyrazole to receptor tyrosine kinase and protein kinase for screening potential inhibitors. Bioinformation 2014;10:413-8.

37. Vadivelan S, Sinha BN, Irudayam SJ, Sarma Jagarlapudi ARP. Virtual screening studies to design potent CDK2-cyclin inhibitors. J Chem Inf Model 2007;47:1526-35.

38. N-(Cycloalkylamino)acyl-2-aminothiazole inhibitors of cyclinDependent kinase 2. N-[5-[[[5-(1,1-dimethylethyl)-2oxazolyl]methylthio]-2-thiazolyl]-4-piperidine-carboxamide (BMS-387032), a highly efficacious and selective antitumour agent. J Med Chem 2004;47:1719-28.

\section{How to cite this article}

- Manisha S Phoujdar, Gourishankar R Aland. Molecular docking study on $1 H-(3,4 d)$ pyrazolopyrimidines as cyclin-dependant kinase (CDK2) inhibitors. Int J Curr Pharm Res 2017;9(1):94-100. 